\title{
Meluruskan Makna Demokrasi
}

Apabila dihitung sejak pertama kali diterbitkan, yaitu pada tahun 1976, maka Padjadjaran Jurnal IImu Hukum (PJIH) ini akan mendekati usia 40 tahun. Satu usia yang bukan saja matang, tapi seharusnya berada pada periode puncak (keberhasilan) periode emas. Tahun ini (2014), PJIH belum genap berusia 40 tahun, dan masih tersisa dua tahun menuju periode puncak. Saat ini, PJIH ditangani oleh manajemen baru, tepatnya dikelola oleh para dosen muda dengan semangat dan visi baru untuk menjadikan PJIH bukan hanya sebagai medium pemenuhan angka kumulatif formal untuk melengkapi syarat kenaikan pangkat, tapi terkandung hasrat kuat untuk menjadikan jurnal ini sebagai wahana yang mampu memfasilitasi interaksi pemikiran yang kritis, objektif, dan jujur.

Dalam perjalanan sejarahnya, PJIH pernah menjadi medium ilmiah yang cukup berwibawa, bukan saja bagi para dosen di Fakultas Hukum Universitas Padjadjaran, tapi juga dosen-dosen di fakultas hukum lain di Indonesia. Jurnal ini sempat dipimpin oleh figur-figur yang berwibawa dan kompeten seperti Prof. Mochtar Kusumaatmadja, Prof. Sri Sumantri, dan Prof. E. Saefullah Wiradipradja. Seiring dengan perjalanan waktu dan penataan regulasi terkait dengan penerbitan berkala ilmiah kampus, PJIH harus merespon dan melakukan beberapa penyesuaian dengan tujuan pokok untuk menjadikannya sebagai jurnal ilmiah rujukan, bukan saja di level nasional, tapi juga di level internasional. Dalam sisa waktu dua tahun ini, manajemen baru diberi mandat dan amanat untuk membawa PJIH pada periode puncak keberhasilan, yakni pada tahun 2016. Keberhasilan yang dimaksud adalah: satu, keberhasilan antara, yaitu memperoleh akreditasi dari Direktorat Jenderal Pendidikan Tinggi (Dikti); kedua, menggapai keberhasilan yang hakiki yaitu menjadikan artikelartikel yang dimuat di jurnal ini sebagai artikel rujukan yang ter-indeks oleh Lexis, West Law, dan Scopus.

Penerbitan perdana PJIH tahun ini berbarengan dengan perhelatan demokrasi lima tahunan (Pemilihan Umum). Untuk menyambut perhelatan demokrasi tersebut yang telah dilaksanakan dan berlangsung relatif aman, nomor perdana ini akan dibuka dengan artikel kehormatan yang ditulis oleh Prof. Bagir Manan, mantan Ketua Mahkamah Agung dan juga Guru Besar Senior Hukum Tata Negara, Fakultas Hukum Unpad, dan Susi Dwi Harijanti, Ph.D., dosen senior Hukum Tata Negara Fakultas Hukum Unpad, alumnus the University of Melbourne. Artikel dengan judul, Saat Rakyat Bicara: Demokrasi dan Kesejahteraan, dengan sangat kritis menyoroti capaian demokrasi di Indonesia yang cenderung fokus pada aspek prosedural, namun abai terhadap substansi demokrasi yaitu pelibatan rakyat secara substansial (deliberatif). 
Demokrasi prosedural rentan untuk menjadi sebuah proses politik yang manipulatif, karena menjadikan rakyat hanya sebagai "voters" (pemilih) yang diundang hadir sekali dalam lima tahun. Artikel ini menawarkan demokrasi konsensus sebagai jalan keluar, satu tawaran bentuk demokrasi yang dianggap lebih mencerminkan realitas sosial masyarakat Indonesia sekaligus lebih mendekati pesan ideologis dan historis pendirian negara Republika Indonesia.

Demokrasi konsensus ditawarkan sebagai sarana yang paling pas untuk mencapai kesejahteraan sosial. Dalam pengertian ini demokrasi tidak dimaknai secara sempit sebagai demokrasi politik yang hanya mengandalkan partisipasi rakyat, yang umumnya dilakukan lewat mekanisme pemilihan umum, tapi juga dimaknai sebagai demokrasi ekonomi yang berujung pada kesejahteraan sosial. Demokrasi konsensus yang juga sering disebut sebagai "negotiation democracy", selain sebagai koreksi terhadap demokrasi mayoritas yang rentan menjadi bias yang menjurus kepada peminggiran pihak minoritas, juga dimaksudkan sebagai demokrasi yang lebih substantif, karena membuka ruang bagi adanya negosiasi-negosiasi konstruktif. Demokrasi konsensus lebih merupakan sebuah demokrasi yang berorientasi pada kualitas (qualitative democracy), sedangkan demokrasi prosedural lebih berorientasi pada sisi kuantitas (quantitative democracy).

Baik tradisi demokrasi Barat ala Athena-Yunani dengan akar kata "demos" atau "damos", maupun demokrasi tradisi Timur ala Sumeria dengan akar kata "dumu", keduanya mewariskan esensi dan pesan yang sama bahwa demokrasi adalah sesuatu yang terkait dengan mayoritas yang "lemah", yaitu rakyat. Demokrasi adalah aspirasi mayoritas rakyat untuk menggapai asa kemuliaan sebagai manusia. Oleh karenanya substansi demokrasi harus berwujud kesejahteraan ekonomi, keadilan sosial, keamanan dan kenyamanan hidup. Medium atau sarana politik seperti pemilihan umum (general election) yang menempatkan rakyat sebagai pemilih adalah metode untuk mencapai tujuan demokrasi, ia hanyalah prosedur bukan esensi demokrasi. Namun, sejarah kemudian mendistorsi sekaligus mereduksi makna demokrasi menjadi identik dengan pemilihan umum dengan berbagai bentuk dan varian lokal masing-masing negara. Demokrasi hanya menjadi prosedur rutin politik daripada esensi sebuah aspirasi publik.

Demokrasi prosedural menempatkan "demos" hanya sebagai objek diam yang diperlukan dan ditempatkan sebagai stempel politik lewat pemilihan umum. Sementara itu demokrasi substantif justru menempatkan "demos" sebagai pemilik suara dan aspirasi yang secara langsung dilibatkan dalam setiap proses demokrasi. Para pakar menyebutnya dengan istilah demokrasi deliberatif. Sehubungan dengan hal ini, llya Somin mengatakan sebagai berikut: "Advocates of 'deliberative democracy' want citizens to actively participate in serious dialogue over political issues, not merely go to the polls every few years (llya Somin: 2010). Demokrasi deliberatif adalah demokrasi yang menempatkan rakyat sebagai bagian penting dan menentukan dalam mewujudkan aspirasi demos menuju kemulian sebagai manusia. Demokrasi deliberatif mengubah rakyat dari objek menjadi subjek demokrasi. 
Fakta dan perjalanan sejarah membuktikan bahwa demokrasi deliberatif yang bermakna pelibatan rakyat secara verbal formal dalam proses deliberasi politik, meskipun bukan sebuah kemustahilan tapi sulit untuk diwujudkan. Pemilihan langsung mungkin dikatakan sebagai demokrasi deliberatif yang paling rasional. Tapi yang sebenarnya terjadi bukan proses deliberasi yang membuka ruang bagi rakyat untuk bicara, tapi hanya sebatas pengumpulan suara. Demokrasi perwakilan (representative democracy) kemudian menjadi pilihan dengan tujuan untuk menghasilkan wakil-wakil rakyat (semacam Ahlul Halli wal Aqd dalam khazanah Fiqh Politik Islam) yang diharapkan dapat mewakili rakyat untuk melakukan deliberasi politik yang jujur dan terpercaya. Namun, sejarah membuktikan demokrasi perwakilan hanya menghasilkan wakil-wakil yang lebih banyak berbicara dan bersuara atas nama dirinya, sangat jarang bahkan tidak pernah melakukan deliberasi politik sebagaimana diamanatkan oleh rakyat.

Demokrasi perwakilan yang cenderung membajak substansi demokrasi harus diakhiri. Persoalannya adalah adanya kontradiksi permanen dalam bangunan demokrasi itu sendiri yaitu rakyat sebagai pemilik demokrasi yang pasti berwujud kuantitas, sesuatu yang hampir mustahil untuk dilibatkan secara formal dalam proses deliberasi politik. Namun, ada satu hal yang senantiasa tunggal dan permanen dalam diri demos yaitu aspirasi kemuliaan sebagai manusia yang berwujud kesejahteraan, keamanan dan kenyamanan hidup, perlindungan HAM, dan seterusnya. Tanpa perlu disuarakan, aspirasi asli demos senantiasa ada dan hidup. Dalam konteks ini maka demokrasi perwakilan dapat melahirkan demokrasi substantif sepanjang para wakil rakyat dapat memahami dan mewujudkan aspirasi tersebut dalam proses deliberasi politik. Dalam kaitan ini, kapabilitas dan etika politik menjadi prasyarat mutlak bagi mereka yang menyediakan dirinya untuk menjadi wakil rakyat.

Para pendiri Republik ini sudah mewasiatkan demokrasi deliberatif lewat penggunaan istilah musyawarah sebagaimana termaktub dalam sila ke-4 Pancasila; "Kerakyatan yang dipimpin oleh hikmat kebijaksanaan dalam permusyawaratan/perwakilan". Musyawarah adalah terminologi religius yang berasal dari kata "syawara" (bahasa Arab) yang berarti mengumpulkan madu. Dengan makna leksikal seperti ini, kita harus mengaitkannya dengan hewan yang identik dengan madu yaitu lebah. Lebah adalah hewan yang tidak terlalu besar juga tidak terlalu kecil, tapi senantiasa tampil elegan dan berwibawa. Dia senantiasa mendatangi tempat yang baik yaitu bunga dan pergi membawa kebaikan yang kemudian dikumpulkan dengan sabar yang akhirnya menjadi madu. Lebah tidak pernah mengkonsumsi madu yang dihasilkannya, tapi sepenuhnya didedikasikannya untuk pihak lain di luar dirinya yaitu manusia. Madu adalah minuman sehat dan menyehatkan. Musyawarah adalah suatu proses dan aktivitas yang harus dilakukan oleh wakil rakyat yang memiliki karakteristik seperti lebah. Sila ke-4 dengan tepat menggandengkan permusyawaratan/perwakilan yang mengisyaratkan bahwa musyawarah tidak bisa dilakukan oleh sembarang orang, hanya oleh wakil rakyat (perwakilan) yang memiliki karakteristik seperti lebah. Mereka yang senantiasa mendatangi tempat yang baik, 
tahu kebaikan dan senantiasa membawa dan menghasilkan kebaikan. Selain itu, mereka juga adalah sosok yang harus sudah selesai dengan dirinya sendiri, tidak serakah. Lebah tidak pernah meminum madu yang dihasilkannya. Musyawarah harus menghasilkan produk yang "sehat" dan menyehatkan seluruh rakyat seperti halnya madu. Dalam kosakata publik, madu adalah representasi dan simbolisasi dari kesejahteraan sosial, semua orang mendambakan dan memerlukannya.

Melengkapi wacana demokrasi sejumlah artikel dengan topik mengenai HAM, hukum tata negara, hukum internasional, hukum acara, hukum zakat, dan kejahatan dunia maya (cybercrime) yang ditulis para pakar di bidangnya disajikan dalam nomor ini dengan harapan dapat menjadi bahan interaksi keilmuan yang kritis dan objektif. Pemuatan artikel-artikel tersebut telah melalui proses penyuntingan baik yang dilakukan oleh mitra bestari maupun editor ahli. Meskipun demikian, substansi dari artikel-artikel tersebut tidak berarti sepenuhnya mencerminkan dan sesuai dengan pandangan redaksi. Artikel-artikel tersebut sepenuhnya merupakan pandangan dan tanggung jawab dari para penulisnya.

Bandung, April 2014

Redaksi 